\title{
REVIEW OF THE HARVEST MICE (GENUS REITHRODONTOMYS) IN THE MEXICAN STATE OF MÉXICO
}

\author{
Noé González-Ruiz ${ }^{1,2}$, José Ramírez-Pulido², and Hugh H. Genoways ${ }^{3}$
}

\begin{abstract}
Aвstract.-We examined 590 specimens of Reithrodontomys from 95 localities in the state of México. Four species of the subgenus Reithrodontomys and 1 of the subgenus Aporodon were identified. The former subgenus included $R$. chrysopsis, R. sumichrasti, R. megalotis, and R. fulvescens, which has 2 subspecies-R. f. toltecus and R. f. mustelinusin the state. The representative of the subgenus Aporodon is $R$. microdon wagneri, which is recorded for the first time in the state. We give information on taxonomy, morphometrics, reproduction, habitat characteristics, and related fauna. A discriminant analysis correctly classified $100 \%$ of specimens from the 6 taxa with 5 canonical variates, and accounted for $96.1 \%$ of the variance with the first 3 canonical variates.
\end{abstract}

Key words: rodents, Reithrodontomys, distribution, taxonomy, state of México, México.

REsumen.-Se examinaron 590 ejemplares de las especies del género Reithrodontomys procedentes de 95 localidades del Estado de México. Se identificaron cuatro especies del subgénero Reithrodontomys y una del Aporodon, del primero, $R$. chrysopsis, R. sumichrasti, $R$. megalotis y $R$. fulvescens, de ésta última se identificaron dos subespecies $R$. $f$. toltecus y R. $f$ mustelinus. La especie del subgénero Aporodon es $R$. microdon wagneri que se registra por primera vez para el Estado. De cada taxon se dan medidas, comentarios taxonómicos y de la condición reproductora, así como las características del hábitat y de la fauna asociada. Un análisis discriminante mostró el 100\% de certeza en la identificación de los 6 taxa y los primeros tres vectores canónicos expresaron el 96.1\% de variación total.

Palabras clave: roedores, Reithrodontomys, distribución, taxonomía, Estado de México, México.

Relatively few papers dealing with the genus Reithrodontomys from the Mexican state of México have been published. The oldest paper known to us is Merriam (1901), in which appeared the description of Reithrodontomys chrysopsis based on specimens from Volcan Popocatépetl. In the same paper, Merriam (1901) also described $R$. tolucae from the Nevado de Toluca, but Howell (1914) in his revision of the genus Reithrodontomys recognized $R$. tolucae as a subspecies of $R$. chrysopsis. Merriam (1901) also recorded the presence of $R$. megalotis and R. fulvescens in the state of México. Hooper (1952) in his review of Latin American harvest mice reported records of several species in the state: $R$. tolucae was retained as a junior synonym of $R$. chrysopsis, and $R$. sumichrasti was recorded for the 1st time from the state of México. Other papers contributing to our understanding of the genus in the state are those by Davis (1944), VillaRamírez (1953), and Ramírez-Pulido (1969).

Because available information is scarce, our purpose is to document the data for species of Reithrodontomys in the state of México. These data have accumulated over the past 35 years in the mammal collection of the Escuela Nacional de Ciencias Biológicas del Instituto Politécnico Nacional. We present information for R. chrysopsis, R. sumichrasti, R. megalotis, $R$. fulvescens (represented by 2 subspeciesR. f. toltecus and R. f. mustelinus) and Reithrodontomys microdon wagneri, which is recorded herein for the 1st time from the state of México. With a sample of 590 specimens of the 5 species, we evaluate, compare, and contrast the taxonomy, morphometrics, reproduction, and habitat characteristics of these species.

\footnotetext{
${ }^{1}$ Universidad Autónoma Metropolitana, Unidad Iztapalapa, División de C.B.S., Departamento de Biología, Apartado Postal 55-535, México 09340, D.F México.

${ }^{2}$ Laboratorio de Cordados Terrestres, Escuela Nacional de Ciencias Biológicas, Instituto Politécnico Nacional, Prolongación de Carpio y Plan de Ayala, Colonia Santo Tomás, Apartado Postal CON 256, 11340, D.F. México. E-mail: jrp@xanum.uam.mx

${ }^{3}$ University of Nebraska State Museum and School of Natural Resources Sciences, W436 Nebraska Hall, University of Nebraska-Lincoln, Lincoln, NE 68588-0514.
} 


\section{Methods}

We examined and analyzed 590 specimens from 95 localities in the state of México (Appendix). For each species, the specimens examined are listed by locality. In the additional records sections, only verified records were entered. Place of origin, reproductive data, and body measurements were obtained from the tag of each specimen. Ecological data, capture conditions, and information about associated fauna and vegetation were obtained from field notes preserved in the collection.

Using a digital caliper precise to $0.01 \mathrm{~mm}$, we measured skulls according to methods of Hooper (1952). Measurements were taken only from adult specimens, which were identified by the degree of wear on the occlusal surface of the molars. Adults also generally showed worn labial and lingual cuspids and absent reentrant angles of M2 and M3. Measurements were the following: total length (TL), length of tail vertebrae (TV), length of hind foot (HF), length of ear (LE), greatest length of skull (GLS), zygomatic breadth (ZB), cranial breadth (CB), interorbital constriction (IC), breadth of rostrum (BR), length of nasals (LN), length of maxillary toothrow (LMTR), breadth of zygomatic plate (BZP), and breadth of mesopterygoid fossa (BMF).

Geographic coordinates of the localities sampled (Appendix) were gathered by 2 methods: (1) GPS in situ and (2) a map scaled at 1:250,000 and published by INEGI (Instituto Nacional de Estadística y Geografía). The localities where specimens were captured and the major types of vegetation are shown in Figure 1.

For comparisons between 2 samples, we used separate-variance $t$ tests with the correction of Welch to obtain a greater sensitivity to differences between means than the Tukey test provides. For comparison of $\geq 3$ samples we used analysis of variance (ANOVA) coupled with a Tukey test for multiple comparisons to define the significance level of differences among means, minimums, and maximums of the 6 groups considered. The 3 significance levels that we considered were $P$-values $<0.05$, $<0.01$, and $<0.001$.

Basic statistics (i.e., mean, minimum, maximum, standard deviation $[s]$, and number of specimens measured $[n]$ ) were obtained from GraphPad Prisma (Motulsky 2003) software.
In order to compare measurements of specimens of all taxa examined, we ran a multivariate analysis of variance (MANOVA); and to demonstrate the separation among species, we used a discriminant analysis with NCSS (Hintze 2000). However, in both cases, we did not include the weight. Significance levels in the MANOVA were tested using Wilks' lambda, Hotelling-Lawley trace, Pillai's trace, and Roy's largest root.

\section{Species ACCOUnTS}

\section{Reithrodontomys (Aporodon) microdon wagneri Hooper, 1950}

SPECimens EXAmined (3). - $2.7 \mathrm{~km} \mathrm{~N}, 9 \mathrm{~km}$ W Villa del Carbón, $2670 \mathrm{~m}$ (1); Llanos de Aculco, $3200 \mathrm{~m} \mathrm{(1);} 1.5 \mathrm{~km} \mathrm{S,} 5 \mathrm{~km} \mathrm{E} \mathrm{San}$ Rafael (1).

This is 1 of the rarest species of the genus. Its distribution is restricted to the mountainous zones of Guatemala, the states of Chiapas and Oaxaca, and central México. The subspecies $R$. m. wagneri was known previously from only 4 specimens: 2 from a locality in México City and 2 from a locality in the state of Michoacán (Hooper 1952). As a result, our specimens significantly increased the number of referred specimens and the number of known localities for the taxon. These are the 1st record for the state of México.

MorPhOLOGY AND DISTRIBUTION.-Reithrodontomys microdon is the only species of the subgenus Aporodon in central México. Members of this subgenus are characterized by having the 2nd primary lingual fold of M3 very well developed so that it appears as an internal enamel island. Other characters distinguishing this species are as follows: zygomatic plate narrow but broader than the width of the mesopterygoid fossa, zygomatic breadth only slightly wider than the cranial breath, and the rostral region tending to be relatively long and narrow (Table 1).

Specimens we examined were larger than those reported by Hooper (1952), particularly the body measurements (Table 1 ) of the 2 Michoacán specimens. The results of ANOVA showed that $R$. m. wagneri is significantly smaller than R. f. toltecus, R. f. mustelinus, and R. s. sumichrasti in BPZ $(P<0.05, P<0.001$, and $P<0.001$, respectively), significantly larger than $R$. f. mustelinus in $\mathrm{ZB}, \mathrm{CB}(P<0.001)$, 


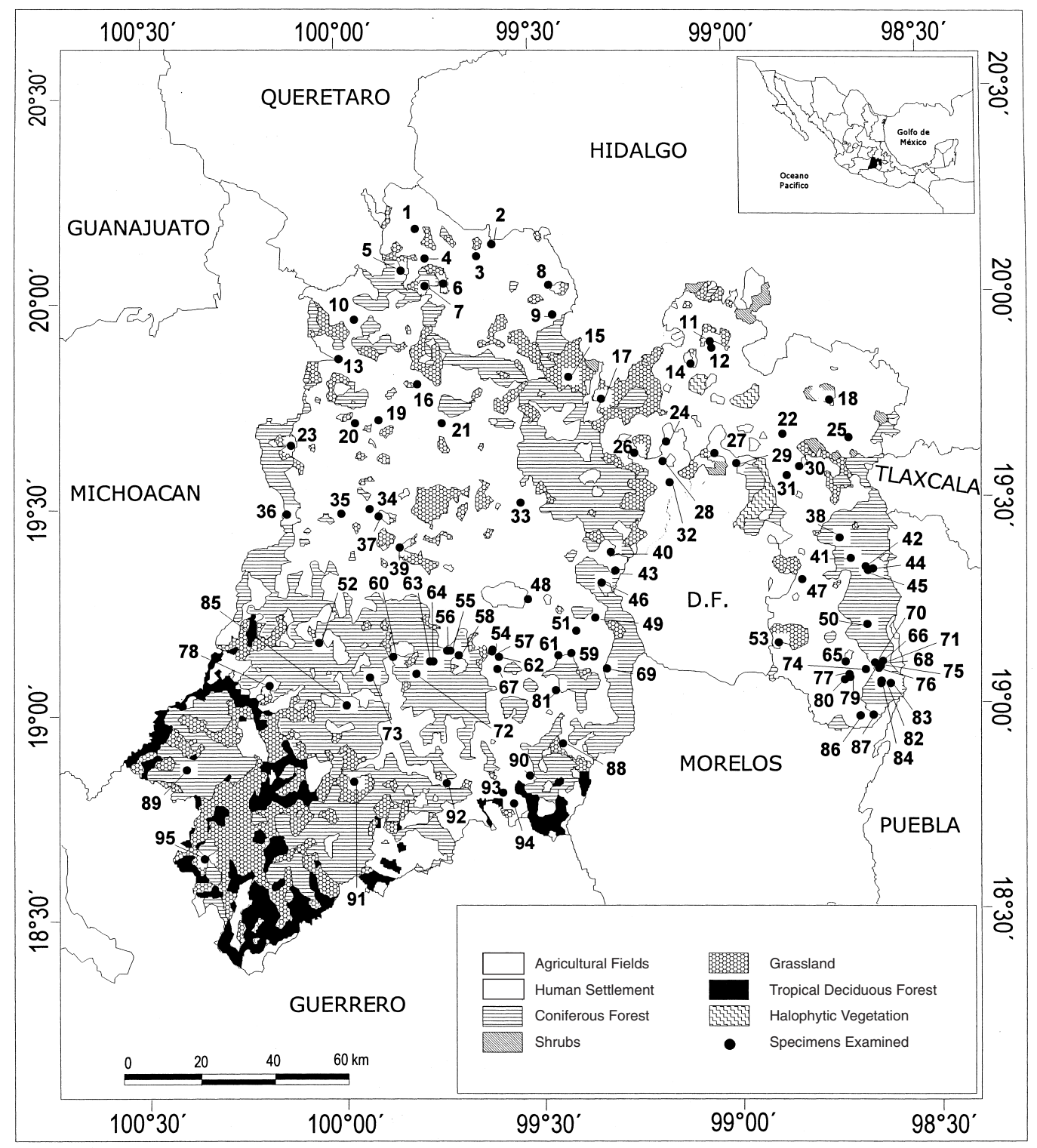

Fig. 1. Index and regional map of the Mexican state of México. Numbers and dots correspond to the gazetteer in the Appendix.

and IC $(P<0.05)$, and significantly larger than R. s. sumichrasti in TV $(P<0.001)$ and IC $(P<0.05)$.

ECOLOGY.-The specimen from Villa del Carbon was a female collected on 11 January 1986. There was no evidence of gross reproductive activity, and the capture location was in a forest of oak mixed with fir and pine; the ground was damp with a large amount of moss. The sex of the specimen from Llanos de Aculco is unknown because it was recovered in a re- gurgitant, probably from an owl. The specimen from San Rafael was a female that showed no active signs of reproduction. This individual was trapped in a pine-oak forest (Fig. 1) with an abundant herbaceous stratum consisting of clusters of plant shoots. Other species taken at these same sites included Microtus mexicanus, Neotomodon alstoni, Peromyscus maniculatus, P. melanotis, and P. difficilis. Apparently, this species occupies a specialized habitat niche because the few known specimens have been 


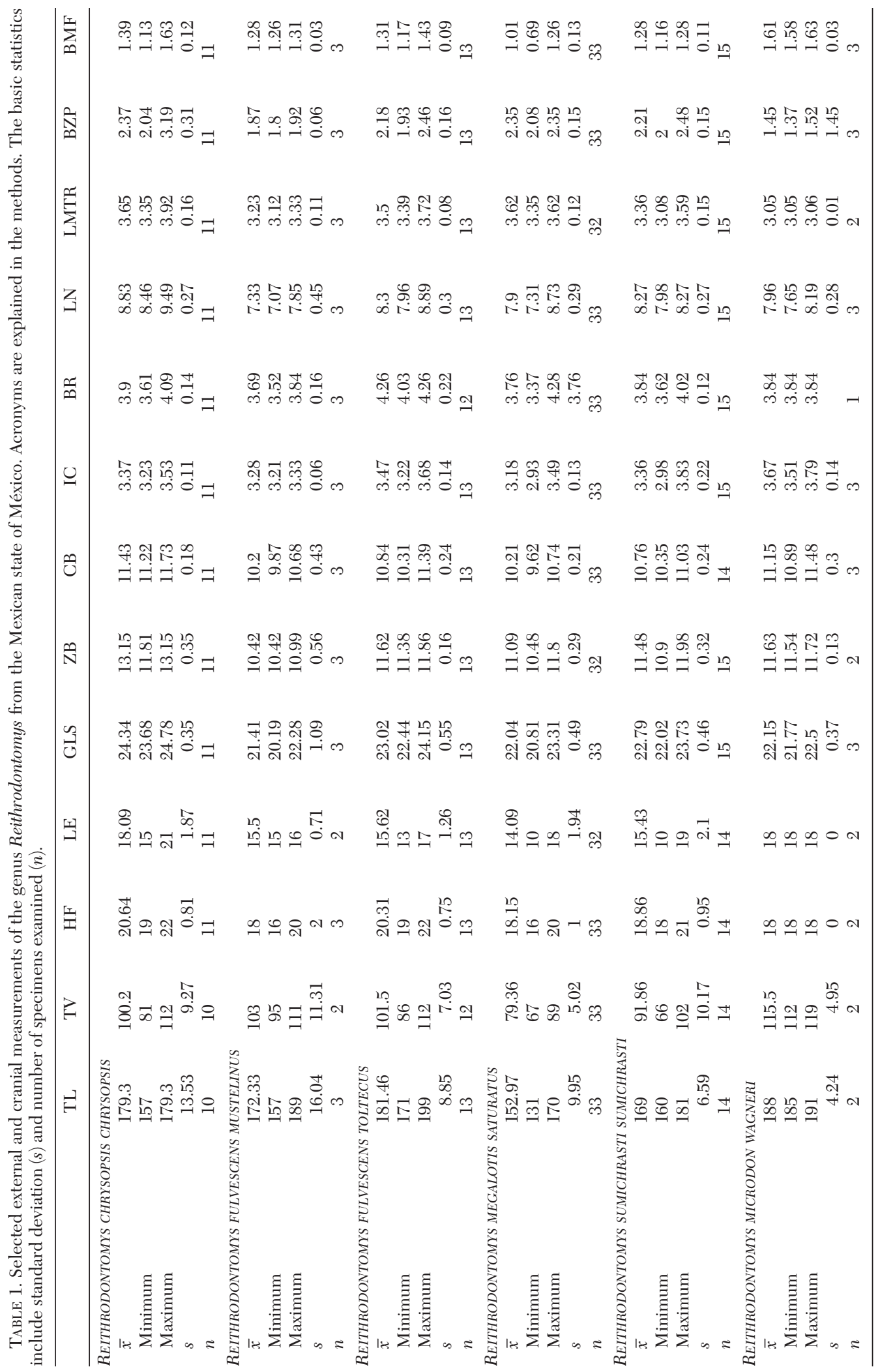


found in oak forests with abundant herbaceous vegetation and are generally associated with very humid zones (Hooper 1952). These conditions are similar to those at the localities in the state of México. The opinion of Hooper (1952) is that this species is probably arboreal.

\section{Reithrodontomys (Reithrodontomys) chrysopsis chrysopsis Merriam, 1900}

Specimens eXamined (33). - $4 \mathrm{~km} \mathrm{~S}, 9 \mathrm{~km}$ E Amecameca, $3480 \mathrm{~m} \mathrm{(5);} 11 \mathrm{~km} \mathrm{~N}, 2.5 \mathrm{~km} \mathrm{~W}$ Coatepec de Harinas, 2820 m (2); Nevado de Toluca (1); $11 \mathrm{~km} \mathrm{S,} 2.5 \mathrm{~km}$ W San Juan de las Huertas, $3780 \mathrm{~m} \mathrm{(2);} 11.5 \mathrm{~km} \mathrm{S,} 2.5 \mathrm{~km}$ W San Juan de las Huertas, $3780 \mathrm{~m} \mathrm{(2);} 12$ km S San Juan de las Huertas, $3850 \mathrm{~m}$ (2); $5.2 \mathrm{~km}$ E San Pedro Nexapa, $3250 \mathrm{~m} \mathrm{(1);} 4 \mathrm{~km} \mathrm{~S}, 8.5 \mathrm{~km} \mathrm{E}$ San Pedro Nexapa, $3500 \mathrm{~m}$ (2); $5.5 \mathrm{~km}$ E San Pedro Nexapa, 3250 m (2); 7 km SE San Pedro Nexapa, 3010 m (2); 2.2 km N, 6.5 km E San Pedro Nexapa, $3490 \mathrm{~m}$ (3); $1.6 \mathrm{~km} \mathrm{~N}, 6.4 \mathrm{~km} \mathrm{E}$ San Pedro Nexapa, $3200 \mathrm{~m}$ (5); 8 km N, 17.5 km E San Simón de Guerrero, 2940 m (2); $15.5 \mathrm{~km} \mathrm{S,} 7 \mathrm{~km} \mathrm{~W}$ Zinacantepec, $3470 \mathrm{~m} \mathrm{(1);}$ $18.5 \mathrm{~km} \mathrm{S,} 9 \mathrm{~km}$ W Zinacantepec, $3440 \mathrm{~m}$ (1).

AdDitional ReCORds.-Volcán Popocatépetl, $11,500 \mathrm{ft}$ (type locality of $R$. $c$. chrysopsis; Merriam 1900, Hooper 1952); Volcán de Toluca, $11,500 \mathrm{ft}$ (type locality of $R$. c. tolucae; Merriam 1901, Hooper 1952, Howell 1914); Monte Río Frío, $55 \mathrm{~km}$ ESE México City, 10,500ft; Ladera N del Mt. Popocatépetl, 13,500 ft (Davis 1944); 8 mi ESE Amecameca, $11,500 \mathrm{ft} ; 28 \mathrm{mi}$ ESE México City, Monte Río Frío, 10,500 ft; 19 mi E Amecameca, Paso Cortes, 11,300 ft; Salazar, $9000 \mathrm{ft}$; Volcán Ixtaccíhuatl, 13,500ft; slopes $\mathrm{W}$ and $\mathrm{SW}$ del Volcán de Toluca [= Nevado de Toluca], 11,400-12,200 ft (Hooper 1952); Paso de Cortes (Villa-Ramírez 1953); Zoquiapan (Mass et al. 1981); 6 km E Amecameca, Vivero Izta-Popo (León and Romo 1991).

MorPhology, Distribution, AND TAXONOMIC COMMENTS.-Reithrodontomys chrysopsis is an endemic Mexican species distributed throughout the Transvolcanic Belt from Veracruz to Colima. In the state of México, it occurs on the volcanoes of Nevado de Toluca, Popocatépetl, and Ixtaccíhualt. Hooper (1952) concluded that the taxon described by Merriam (1901) as R. tolucae is a junior synonym of $R$. c. chrysopsis, and we agree with this assessment. Examination of a large sample of specimens from the area surrounding Volcan Nevado de Toluca and comparison of these specimens with a series from the Sierra Nevada revealed no morphological differences to justify a different conclusion.

Reithrodontomys chrysopsis chrysopsis was significantly larger than $R$. megalotis saturatus in TL, TV, HF, LE, and IC $(P<0.001) ; R$. $s$. sumichrasti in HF, LE, LN, BZP $(P<0.001)$, TL, and TV $(P<0.05) ; R$. fulvescens mustelinus in $\mathrm{HF}, \mathrm{LN}$, and BZP $(P<0.001) ; R$. $f$. toltecus in $\mathrm{LN}(P<0.001)$, LE $(P<0.01)$, and BZP $(P<0.05)$; and $R$. microdon wagneri in LN $(P<0.001)$ and HF $(P<0.01$; Table 1$)$.

ECOLOGY.-Two lactating females were taken in May and July and a young individual was obtained in November. Average testis lengths of males by month of collection were as follows: March, $7.5 \mathrm{~mm}(n=4$, range 7.0 $8.0 \mathrm{~mm})$; April, $8.0 \mathrm{~mm}(n=1)$; May, $5.0 \mathrm{~mm}$ and $4.0 \mathrm{~mm}(n=2)$; July, $6.7 \mathrm{~mm}(n=3$, range 3.0-10.0 mm); October, $4.6 \mathrm{~mm}(n=8$, range 3.0-7.0 mm); November, $4.0 \mathrm{~mm}(n=1)$; December, $4.0 \mathrm{~mm}(n=1)$. Although these data are sketchy, it appears that individuals of R. chrysopsis are capable of reproduction from at least March through July, and possibly as late as September.

This species was collected primarily in pine forests, although in San Simon de Guerrero, it was collected in an Abies forest with tall grass (Fig. 1). Generally, this species is captured in rugged terrain where the climate is humid. Individuals of this species were obtained together with Reithrodontomys megalotis, $R$. sumichrasti, Peromyscus melanotis, Neotomodon alstoni, and Microtus mexicanus.

\section{Reithrodontomys (Reithrodontomys) fulvescens J.A. Allen, 1894}

Two subspecies of Reithrodontomys fulvescens have been recorded for the state of México (Ramírez-Pulido et al. 1995, 1997, Chávez and Ceballos 1998). The primary external difference between $R$. f. toltecus and R. f. mustelinus was in dorsal coloration-the former is grayish orange, whereas the latter is bright, light orange.

\section{Reithrodontomys fulvescens toltecus Merriam, 1901}

Specimens examined (126).--El Angostadero 23 km NW Acambay, 2700 m (4); 8.5 km 
$\mathrm{N}, 1.5 \mathrm{~km}$ E Acambay, $2740 \mathrm{~m}(1) ; 12.5 \mathrm{~km} \mathrm{~N}$, $4.5 \mathrm{~km} \mathrm{~W}$ Acambay, $2450 \mathrm{~m} \mathrm{(9);} 3.5 \mathrm{~km} \mathrm{~N}, 19$ $\mathrm{km}$ Aculco, $2650 \mathrm{~m}$ (1); $5 \mathrm{~km}$ W Atenco (2); 1.1 km N Barrientos, $2300 \mathrm{~m} \mathrm{(3);} 4.5$ km E Chiconautla, $2350 \mathrm{~m} \mathrm{(2);} 3 \mathrm{~km} \mathrm{E,} 2 \mathrm{~km}$ S Chilpa, $2270 \mathrm{~m}$ (18); $2 \mathrm{~km}$ S Coacalco, $2440 \mathrm{~m} \mathrm{(7);} 5$ $\mathrm{km}$ E Jilotepec, $2460 \mathrm{~m}$ (14); $8.5 \mathrm{~km} \mathrm{~N}, 2.5 \mathrm{~km}$ E Jilotepec, $2320 \mathrm{~m} \mathrm{(15);} 1 \mathrm{~km} \mathrm{~S}, 2 \mathrm{~km} \mathrm{E}$ Nicolás Romero, $2350 \mathrm{~m} \mathrm{(2);} 2.5 \mathrm{~km}$ W San Francisco Tepojaco, $2350 \mathrm{~m}$ (20); $2.5 \mathrm{~km}$ N San Juan Zitlaltepec, 2250 m (1); Santa María de las Cuevas, $2480 \mathrm{~m}$ (15); 2 km NW Santiago Tolman, $2600 \mathrm{~m} \mathrm{(3);} 6.5 \mathrm{~km} \mathrm{~S}, 6 \mathrm{~km}$ W Temascalcingo, $2560 \mathrm{~m} \mathrm{(3);} 2 \mathrm{~km}$ NW Tlanepantla, 2300 m (4); 9.5 km N Zumpango, 2270 m (2).

AdDitional ReCords.-17-22 km E México City, $7500 \mathrm{ft}$ (Davis 1944); Hacienda Córdoba, $8300 \mathrm{ft}$; 10-13 mi SE México City, 7500 $\mathrm{ft}$ (Hooper 1952); Rancho Córdoba, $2650 \mathrm{~m}$ (Hooper 1947); 4 km ENE Tlalmanalco, 2290 $\mathrm{m}$ (Hall 1981).

MorPhOLOGY.-Reithrodontomys $f$. toltecus differs significantly from $R$. f. mustelinus in GLS, ZB, CB, LN (ANOVA: $P<0.001$ ), and HF $(P<0.01)$, whereas $t$ tests showed differences in IC $(P<0.05)$, RB $(P<0.01)$, and BZP $(P<0.001)$. Reithrodontomys $f$. toltecus averaged larger than $R$. $f$. mustelinus in all measurements.

ECOLOGY.-A female taken in February was pregnant with 4 embryos (crown-rump length $3 \mathrm{~mm}$ ), and a female taken in March was lactating. The remainder of the females collected in January, February, March, April, November, and December showed no gross signs of reproductive activity, although 2 young specimens were taken in February and 1 in November. Males taken in September and November had the largest testes, which may indicate that breeding took place during these months. Average testis lengths of males by month of collection were as follows: January, $3.2 \mathrm{~mm}(n$ $=22$, range $2.0-6.0 \mathrm{~mm}$ ); February, $4.2 \mathrm{~mm}(n$ $=20$, range 2.0-9.0 $\mathrm{mm})$; March, $5.2 \mathrm{~mm}(n=$ 11, range 2.5-10.0 mm); April, $3.0 \mathrm{~mm}(n=1)$; September, $8.3 \mathrm{~mm}(n=4$, range $3.0-11.0$ $\mathrm{mm})$; November, $7.0 \mathrm{~mm}(n=3$, range 3.0-9.0 $\mathrm{mm})$; December, $4.9 \mathrm{~mm}(n=9$, range 2.0 $11.0 \mathrm{~mm})$.

The primary difference in habitat between the subspecies was that $R$. f. toltecus was collected in cold areas of the Mexican Transvolcanic Belt at heights ranging from $2250 \mathrm{~m}$ to $2740 \mathrm{~m}$ in coniferous forests and xerophytic shrubland, whereas $R$. f. mustelinus was found in the warm areas of the Balsas Basin in the southwestern part of the state between 1180 $\mathrm{m}$ and $1900 \mathrm{~m}$ in the low tropical deciduous forest. In fact, Reithrodontomys $f$. mustelinus is the only species of this genus located in this province in the Balsas Basin (Sánchez 1993). In most instances, this subspecies was found in xerophytic shrub and occasionally in oak forest and around Acambay in very altered forests and farmlands (Fig. 1). Species that were caught $\geq 5$ times together with $R$. fulvescens toltecus were Peromyscus gratus, P. maniculatus, and Baiomys taylori. Other associated species taken less frequently were Peromyscus melanophrys, P. difficilis, P. levipes, Perognathus flavus, Sigmodon hispidus, Liomys irroratus, and R. megalotis.

\section{Reithrodontomys fulvescens mustelinus Howell, 1914}

Specimens EXAmined (13).-1 km SW Zacazonapan, $1320 \mathrm{~m} \mathrm{(1);} 3 \mathrm{~km} \mathrm{S,} 8$ km W Sultepec, $1300 \mathrm{~m} \mathrm{(2);} 5 \mathrm{~km} \mathrm{~S}, 5 \mathrm{~km} \mathrm{~W}$ Palmar

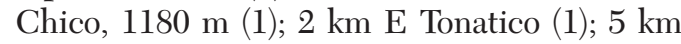
S, $5.5 \mathrm{~km}$ E Tonatico, $1590 \mathrm{~m}$ (3); Cañada de Nanchititla, 1900 m (1); Jalmolonga, $1600 \mathrm{~m}$ (1); Zumpahuacán, 1630 m (3).

AdDitional RECORD.—4 km SSE Tonatico, 1670 m (Sánchez 1993).

ECOLOGY.-A female obtained in February did not show signs of reproductive activity. Three males collected in February had testes that were 5,2 , and $8 \mathrm{~mm}$ long, respectively. One male in October had testes $9 \mathrm{~mm}$ long, and 6 males in November had testes averaging $3.0 \mathrm{~mm}$ long (range $2.0-5.0 \mathrm{~mm}$ ).

This subspecies was found in ravines in the southwestern part of the state and was always related to the low tropical deciduous forest (Fig. 1). Species collected together with this subspecies were Liomys pictus, Oryzomys couesi, Peromyscus melanophrys, and Baiomys musculus.

\section{Reithrodontomys (Reithrodontomys) megalotis saturatus \\ Allen and Chapman, 1897}

Specimens examined (387).--El Angosta-

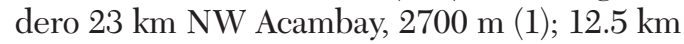
$\mathrm{N}, 4.5 \mathrm{~km}$ W Acambay, $2450 \mathrm{~m}$ (39); $9 \mathrm{~km} \mathrm{~N}$, $7.5 \mathrm{~km}$ E Acambay, $2740 \mathrm{~m} \mathrm{(5);} 8 \mathrm{~km} \mathrm{~N}, 3 \mathrm{~km}$ W Aculco, $2250 \mathrm{~m}(1) ; 3.5 \mathrm{~km} \mathrm{~N}, 19 \mathrm{~km}$ Aculco, 
$2650 \mathrm{~m}$ (24); $6 \mathrm{~km}$ S Amecameca, $2450 \mathrm{~m}$ (1); $5 \mathrm{~km} \mathrm{~W}$ Atenco $\mathrm{m}(6) ; 1 \mathrm{~km}$ E Capulhuac, 2600 m (18); 1 km S, 2 km W Chimalpa, 2900 m (1); $11 \mathrm{~km} \mathrm{~S}, 2.5 \mathrm{~km}$ W Coatepec de Harinas, 2870 $\mathrm{m}(4) ; 1.5 \mathrm{~km} \mathrm{~N}, 5.5 \mathrm{~km}$ E Ecatzingo, $2970 \mathrm{~m}$ (2); $2.5 \mathrm{~km} \mathrm{~N}, 1.5 \mathrm{~km} \mathrm{~W}$ Huixquilucan, $2800 \mathrm{~m}$ (7); $3 \mathrm{~km} \mathrm{~S}$ Huixquilucan, $3000 \mathrm{~m} \mathrm{(1);5} \mathrm{km} \mathrm{E}$ Jilotepec, $2460 \mathrm{~m}$ (2); Cerro Ayaqueme $6 \mathrm{~km}$ $\mathrm{N}, 6.5 \mathrm{~km}$ W Juchitepec, $2910 \mathrm{~m} \mathrm{(6);} 4$ km W La Providencia, 3050 m (3); Cuesta del Carmen $3 \mathrm{~km} \mathrm{~N}, 1 \mathrm{~km}$ W Lengua de Vaca, $2760 \mathrm{~m}$ (5); 3 km E Popo Park, 2480 m (17); Nevado de Toluca 4 km S, 2 km W Raíces, 3350 m (1); 3 km W Río Frío, $3000 \mathrm{~m}$ (4); 9 km W Río Frío, $3050 \mathrm{~m}$ (1); 2 km S, 5 km W Río Frío, $3100 \mathrm{~m}$ (1); $3 \mathrm{~km} \mathrm{S,} 4 \mathrm{~km} \mathrm{~W}$ Río Frío, $3290 \mathrm{~m}$ (1); Salazar, $3050 \mathrm{~m}$ (1); San Felipe del Progreso, $2620 \mathrm{~m} \mathrm{(4);} 1 \mathrm{~km} \mathrm{~S}, 3 \mathrm{~km} \mathrm{~W}$ San José del Rincón, 2960 m (15); 12 km S San Juan de las Huertas, $3850 \mathrm{~m}$ (2); $11.5 \mathrm{~km} \mathrm{S,} 2.5 \mathrm{~km}$ W San Juan de las Huertas, $3720 \mathrm{~m}$ (5); $2.5 \mathrm{~km}$ N San Juan Zitlaltepec, $2250 \mathrm{~m}$ (1); $7 \mathrm{~km}$ SE San Nicolas Coatepec, $2740 \mathrm{~m}$ (3); $0.25 \mathrm{~km} \mathrm{S,} 2.25$ km E San Pedro Atlapulco, $3100 \mathrm{~m} \mathrm{(4);1.5} \mathrm{km}$ E San Pedro Nexapa, $2700 \mathrm{~m}$ (6); 1.5 km N, 4 km E San Pedro Nexapa, 2940 m (8); 6 km E, $4 \mathrm{~km}$ S San Pedro Nexapa, $3050 \mathrm{~m}$ (1); San Sebastian Shala, FES-Cuatitlán (2); $8 \mathrm{~km} \mathrm{~N}$, 17.5 km E San Simón de Guerrero, 2940 m (1); Santa María de las Cuevas, $2480 \mathrm{~m}$ (2); $5 \mathrm{~km} \mathrm{~S}$ Santiago Tianguistenco, $2620 \mathrm{~m} \mathrm{(24);} 4 \mathrm{~km} \mathrm{~N}$, $1.5 \mathrm{~km}$ E Santiago Tilapa, $2750 \mathrm{~m} \mathrm{(5);} 4 \mathrm{~km} \mathrm{~N}$, $1 \mathrm{~km} \mathrm{~W}$ Temascalcingo, $2360 \mathrm{~m}(11) ; 6.5 \mathrm{~km} \mathrm{~S}$, $6 \mathrm{~km} \mathrm{~W}$ Temascalcingo, $2560 \mathrm{~m} \mathrm{(1);} 4 \mathrm{~km} \mathrm{~N}$ Temoaya, $2870 \mathrm{~m} \mathrm{(25);} 7.5 \mathrm{~km}$ E Tenango de Arista, $2600 \mathrm{~m}$ (11); $6 \mathrm{~km} \mathrm{S,} 8.5 \mathrm{~km} \mathrm{~W}$ Tenango de Arista, $2750 \mathrm{~m}$ (35); Texcalyacac, $2570 \mathrm{~m}$ (1); 16 km SW Texcoco, $2220 \mathrm{~m} \mathrm{(1);} 600 \mathrm{~m} \mathrm{SW}$ Tlamacas, $4000 \mathrm{~m}$ (1); $3 \mathrm{~km}$ S Tlapacoya, 2250 m (12); 9 km N Villa del Carbón, 2400 m (2); 6 km NW Villa Victoria, $2400 \mathrm{~m} \mathrm{(11);} 4.5 \mathrm{~km} \mathrm{~S}$,

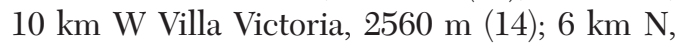
2.5 km W Villa Victoria, 2710 m (19); Criadero San Cayetano 8 km NW Villa Victoria m (1); $15 \mathrm{~km} \mathrm{S,} 7 \mathrm{~km} \mathrm{~W}$ Zinacantepec, $3470 \mathrm{~m} \mathrm{(6);}$ $9.5 \mathrm{~km}$ N Zumpango, $2270 \mathrm{~m}$ (1).

ADDiTIONAL RECORDS. $-5 \mathrm{~km}$ NW Texcoco, 7600 ft; Monte Río Frio, 45-55 km ESE México City, 10,500 ft; Lago Zempoala, 45 km SW México City, $9400 \mathrm{ft}$ (Davis 1944); Rancho Córdoba, 2560-2600 m; Río Frío, 2900-3000 m (Hooper 1947); 5 mi E Amecameca, $9600 \mathrm{ft}$; Atlacomulco, 8200 ft; Lerma, 8500 ft; Lago de
Zempoala, 9400 ft; Rancho Córdoba, 8200-8700 $\mathrm{ft}$; vicinity of Río Frío, 9500-10,500ft; Salazar, 10,000 ft; 3 mi NW Texcoco, $7600 \mathrm{ft}$; Toluca Valley, $9000 \mathrm{ft}$; $15 \mathrm{mi}$ SW Toluca, 10,000 ft; N and NW slope Volcán Popocatépetl, 10,800$13,000 \mathrm{ft}$; N slope Volcán de Toluca, $11,400 \mathrm{ft}$ (Hooper 1952); Paso de Cortes, 35 km E Amecameca, $3450 \mathrm{~m}$; Cerro la Caldera, $17 \mathrm{~km}$ ESE Ciudad de México, $2350 \mathrm{~m}$; N slope Popocatépetl; $2 \mathrm{~km}$ E Villa de Guadalupe, $2350 \mathrm{~m}$ (Villa-Ramírez 1953); Lengua de Vaca; San Cayetano (Hooper 1957); Laguna Prieta, $2900 \mathrm{~m}$; $0.5 \mathrm{~km} \mathrm{SW}$ Laguna Prieta, $2900 \mathrm{~m}$; Cerro Ocuilapan, 3200 m (Ramírez-Pulido 1969); Cerro Gordo, 8 km N San Juan Teotihuacán, $2800 \mathrm{~m} ; 1 \mathrm{~km}$ E San Juan Teotihuacán, 2280 m; 5 km NE Zumpango, $2260 \mathrm{~m}$ (Ceballos and Galindo 1984); 8 km E Zacualpan; El Volcán de Toluca, 11,500 ft; Laguna Quila, Lagunas de Zempoala; Puentecillas (León and Romo 1991); Unidad de Evaluación y Monitoreo de la Biodiversidad, San Cayetano (Cervantes et al. 1995); $6 \mathrm{~km} \mathrm{~N}, 2.5 \mathrm{~km} \mathrm{~W}$ Villa Victoria, $2810 \mathrm{~m}$ (Gaona et al. 2000).

MorPHOLOGY.-Reithrodontomys m. saturatus is significantly smaller than $R$. f. toltecus in TL, TV, GLS, CB, ZB, IC, and LN (ANOVA: $P$ $<0.001)$, R. f. mustelinus in TV $(P<0.001)$, ZB $(P<0.01)$, TL, and LN $(P<0.05), R$. microdon wagneri in TL, TV, CB, and IC $(P<$ $0.001)$, and R. s. sumichrasti in TL, TV, GLS, ZB, CB, IC $(P<0.001)$, and LN $(P<0.01)$. Reithrodontomys $m$. saturatus is significantly larger than R. f. mustelinus and R. microdon wagneri in $\mathrm{HF}(P<0.001$ and $P<0.05$, respectively).

ECOLOGY-Reithrodontomys megalotis is the most abundant mammalian species in the state of México and is probably also the most abundant rodent in the Basin of México (VillaRamírez 1953, Sánchez 1993). It has great environmental plasticity, and has been collected in all types of vegetation in the state, except for the low tropical forest of the southwestern portion of the state (Fig. 1). In many instances, this species was taken in temperate forests, primarily pine-oak, oak, and Abies forests and also often in xerophytic shrubland. In fact, it was most frequently captured in altered environments, most commonly in agricultural fields (Fig. 1). Reithrodontomys megalotis megalotis occupies most areas of the Mexican high plateau, and its southern distribution reaches the 
boundaries of the state of México. Therefore, the examined specimens of $R$. m. saturatus from Aculco confirm the distribution suggested by Hooper (1952).

Six pregnant females were taken: 1 in February with 4 embryos (crown-rump length 15 $\mathrm{mm}$ ); 1 in March with 3 embryos (crown-rump length $12 \mathrm{~mm}$ ); 3 in November with 1, 5, 6 embryos, respectively (crown-rump lengths 14 $\mathrm{mm}, 19 \mathrm{~mm}$, and $2 \mathrm{~mm}$, respectively); and 1 in December with 3 embryos (crown-rump length $22 \mathrm{~mm}$ ). Moreover, 4 lactating females were collected in January, March, September, and November. Apparently this species has a single breeding season lasting from September to March; however, because data are limited, it will be necessary to verify these observations during field research. The mean testis lengths of males by month of collection were as follows: January, $4.0 \mathrm{~mm}(n=39$, range $2.1-10.1$ $\mathrm{mm})$; February, $5.0 \mathrm{~mm}(n=7$, range $2.0-8.0$ $\mathrm{mm})$; March, $4.2 \mathrm{~mm}(n=46$, range $2.0-9.0$ $\mathrm{mm})$; April, $4.4 \mathrm{~mm}(n=25$, range $2.0-8.0$ $\mathrm{mm})$; May, $6.7 \mathrm{~mm}(n=7$, range $5.0-10.0$ $\mathrm{mm})$; June, $5.9 \mathrm{~mm}(n=10$, range $4.0-8.0$ $\mathrm{mm})$; September, $11.0 \mathrm{~mm}(n=1)$; November, $3.9 \mathrm{~mm}(n=29$, range $1.0-11.0 \mathrm{~mm})$; December, $3.4 \mathrm{~mm}(n=14$, range $1.0-11.0 \mathrm{~mm})$.

Species frequently captured along with $R$. megalotis include Liomys irroratus, Peromyscus difficilis, P. levipes, P. maniculatus, P. melanotis, Neotomodon alstoni, Baiomys taylori, and Microtus mexicanus. Other species less frequently captured with $R$. megalotis were Perognathus flavus, Reithrodontomys fulvescens, Peromyscus difficilis, P. maniculatus, P. melanophrys, P. gratus, and Sigmodon hispidus.

\section{Reithrodontomys (Reithrodontomys) sumichrasti sumichrasti (Saussure, 1861)}

Specimens examined (28). - $2 \mathrm{~km}$ NE Chimalpa, $2700 \mathrm{~m}$ (1); $2.5 \mathrm{~km}$ NE Ecatzingo, 2600 m (3); Cuesta del Carmen $3 \mathrm{~km} \mathrm{~N}, 1 \mathrm{~km} \mathrm{~W}$ Lengua de Vaca, $2760 \mathrm{~m} \mathrm{(6);} 2.5 \mathrm{~km}$ E Popo Park, $2470 \mathrm{~m}$ (1); $3 \mathrm{~km}$ E Popo Park, $2480 \mathrm{~m}$ (2); $5 \mathrm{~km} \mathrm{~N}, 2 \mathrm{~km}$ E Real de Arriba, $1980 \mathrm{~m} \mathrm{(2);}$ $11.5 \mathrm{~km} \mathrm{~S}, 2.5 \mathrm{~km} \mathrm{~W}$ San Juan de las Huertas, $3780 \mathrm{~m} \mathrm{(1);} 1 \mathrm{~km} \mathrm{~N}, 0.6$ km E San Juan Tehu-

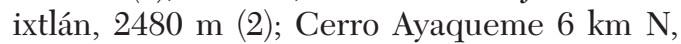
$6.5 \mathrm{~km} \mathrm{~W}$ Juchitepec, $2910 \mathrm{~m} \mathrm{(1);10} \mathrm{km} \mathrm{N,}$ $12.4 \mathrm{~km}$ E Temascaltepec, $2450 \mathrm{~m} \mathrm{(2);} 3 \mathrm{~km} \mathrm{~S}$ Temascaltepec, $1900 \mathrm{~m} \mathrm{(2);} 6 \mathrm{~km} \mathrm{~S}, 8.5 \mathrm{~km} \mathrm{~W}$
Tenango de Arista, $2750 \mathrm{~m}$ (2); 7.5 km E Ten-

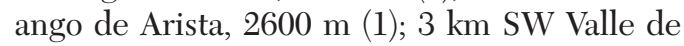
Bravo, 2060 m (1); Criadero San Cayetano 8 km NW Villa Victoria (1).

AdDitional RECORDS.-Hacienda Córdoba, $8300 \mathrm{ft}$ (Hooper 1952); Zoquiapan (Mass et al. 1981); ladera W Popocatépetl, km 15 carretera Amecameca-Tlamacas, $3220 \mathrm{~m}$ (Ceballos and Galindo 1984).

MORPHOLOGY, DISTRIBUTION, AND TAXONOMIC COMMENTS.-Hooper (1952) in his revision of the Latin American Reithrodontomys, suggested that it is $R$. sumichrasti nerterus that occurs in the state of México because this subspecies is distributed in eastern Michoacán. However, the only feature that supports the recognition of $R$. s. nerterus as a subspecies is a lighter ventral coloration than found in $R$. $s$. sumichrasti (Hooper 1952). The specimens from the state of México were compared with specimens of R. s. nerterus and R. s. sumichrasti, but no important differences were found between them; in fact, ventral coloration was highly variable even in populations close to the type localities. For example, 3 of 10 specimens from Pinal de Amoles, Querétaro, had a dark ventral coloration, and 5 of 15 specimens from Colima and Jalisco showed a pale venter. Furthermore, the specimens from western Puebla, México, and México City showed an intermediate color between $R$. s. sumichrasti and R. s. nerterus (Hooper 1952). Owing to the highly variable ventral coloration in these populations, the differences between $R$. s. nerterus and $R$. s. sumichrasti may be clinal variation or simply individual variation. This raises questions about the validity of $R$. s. nerterus; however, it will be necessary to carry out a more careful review to solve this problem.

In the state of México, 14 adult and subadult specimens showed a pale ventral coloration and 10 showed a dark coloration, but this variation did not appear to have any relation to the date of capture nor to the geographic areas of the captures. We tentatively assign our specimens to $R$. s. sumichrasti as the most conservative course of action to follow.

Reithrodontomys s. sumichrasti is significantly smaller than $R$. f. toltecus in TL, TV (ANOVA: $P<0.05)$, and HF $(P<0.01)$ and significantly larger than $R$. f. mustelinus in GLS, ZB, LN $(P<0.001)$, and CB $(P<0.01)$.

Ecology.-A female taken in May carried 3 embryos (crown-rump length $24 \mathrm{~mm}$ ), and in 
August a lactating female and a young individual were captured. Five females captured in February, March, and November showed no gross reproductive activity. Mean testis lengths for males by month of collection were as follows: February, $7.0 \mathrm{~mm}(n=1)$; March, 4.5 $\mathrm{mm}(n=5$, range $3.0-5.0 \mathrm{~mm})$; May, $4.5 \mathrm{~mm}$ and $5.0 \mathrm{~mm}(n=2)$; July, $7.3 \mathrm{~mm}(n=3$, range $6.0-9.0 \mathrm{~mm}$ ); August, $9.0 \mathrm{~mm}$ and 9.0 $\mathrm{mm}(n=2)$; October, $10.0 \mathrm{~mm}(n=1)$; and November, $2.0 \mathrm{~mm}(n=1)$.

In general, this species was found in pine, pine-oak, oak, and Abies forests, but they also were collected in grass and farming areas (Fig. 1). In Tenango de Arista, a specimen was captured in its nest under a log. This species was taken together with Liomys irroratus, Reithrodontomys chrysopsis, R. megalotis, Peromyscus aztecus, P. difficilis, P. levipes, P. maniculatus, $P$. melanotis, Neotomodon alstoni, and Microtus mexicanus.

\section{Discussion}

The state of México can be divided into 2 main regions based on its physiographic and climatic characteristics and types of vegetation. The largest region is the temperate zone covering the northern and central parts of the state and belonging to the Mexican Transvolcanic Belt. Its elevations range from $2200 \mathrm{~m}$ to $5400 \mathrm{~m}$ at the summit of the Popocatépetl Volcano, and climate of the region is both temperate and cold. In this province, pine-oak forests prevail, although xerophytic shrub also is abundant, especially in the northern part of the state along the boundary with the state of Hidalgo. In this zone, the vegetation has suffered intensive alteration and destruction due to human activities, uncontrolled felling of trees, creation of new farm and pasture lands, and fundamentally the resulting soil erosion. The hot region is located in the southwestern part of the state and is directly related to the province of the Balsas Basin. Vegetation is almost exclusively thorn deciduous forest; the climate is hot; and the elevation is $<2200 \mathrm{~m}$, with the lowest areas being at $450 \mathrm{~m}$.

Even though species of Reithrodontomys are located in both regions, the records of $R$. chrysopsis, R. megalotis, R. microdon, and $R$. sumichrasti confirm that they belong to the temperate zone. On the other hand, R. fulvescens shows a clear ecological separation in the distribution of its subspecies. Reithrodontomys $f$. toltecus has a wide distribution but only in the temperate zone, and R. f mustelinus belongs exclusively to the Balsas Basin (Fig. 1). The existence of $R$. $f$ mustelinus as the only taxon in the Balsas Basin probably is the result of its greater tolerance of environmental conditions that restrict the other species in the same genus (Sánchez, 1993).

The co-occurrence of several Reithrodontomys species in the Mexican Transvolcanic Belt portion of the state of México allows evaluation of the geographic distribution of each species in relation to a definite habitat type. For example, R. chrysopsis is found only on the sides of the large volcanoes Nevado de Toluca, Popocatépetl, and Iztaccíhuatl, above $2800 \mathrm{~m}$ ( = $3375 \mathrm{~m}$ ) with pine forest associations, but primarily with fir forest (Abies religiosa; Fig. 1). Reithrodontomys megalotis and R. sumichrasti are found in all types of vegetation of the temperate region of the state: oak forest, pine forest, and fir forest, with their respective ecotones and understory types. Both species are distributed over a large altitudinal range, which varies from $2000 \mathrm{~m}$ to $3330 \mathrm{~m}$ for R. megalotis and $1900 \mathrm{~m}$ to $3780 \mathrm{~m}$ for R. sumichrasti. Reithrodontomys fulvescens toltecus is restricted to xerophytic shrubland at locations where elevations range from 2250 $\mathrm{m}$ to $2740 \mathrm{~m}$. R. microdon is a species for which few specimens are known; it has habits of a tree-dwelling species, making its capture very difficult (Hooper 1952). The rare localities of this taxon are found in very humid places in oak forests (Fig. 1) with 1.5-m-high understory.

Notwithstanding the types of vegetation shared by the different species, the selection of their habitats is distinctive. In fact, only in 18 out of 95 localities (19\%) were 2 or more species collected together, and at all of these localities, the most common species was $R$. megalotis. It was sympatric with $R$. chrysopsis at 3 localities, with $R$. sumichrasti at 7 localities, and with R. fulvescens toltecus at 8. Only at 1 locality $(11.5 \mathrm{~km} \mathrm{S,} 2.5 \mathrm{~km}$ W San Juan de las Huertas) were individuals from 3 species collected in the same trap line (R. chrysopsis, R. sumichrasti, and R. megalotis). R. megalotis is a species with great environmental plasticity. It is the most abundant species, and the only one found in altered zones, such as agricultural fields or pasture (Hooper, 1952). 


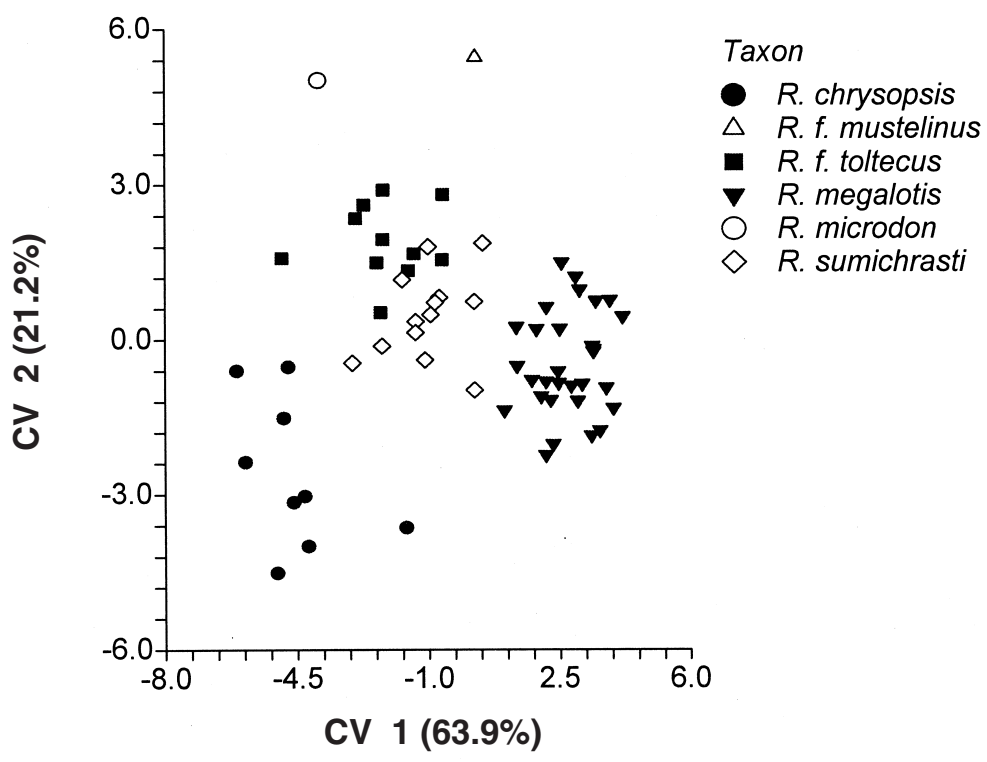

Fig 2. First and 2nd canonical variates resulting from disciminant analysis showing relationships among 65 specimens of Reithrodontomys: R. chrysopsis $(n=9)$, R. fulvescens mustelinus $(n=1), R$. $f$. toltecus $(n=11)$, R. megalotis $(n=30)$, $R$. microdon $(n=1), R$. sumichrasti $(n=13)$. The canonical correlation values from the 1st and 2nd canonical correlation are in Table 2.

According to results from MANOVA (4 commonly used test statistics: Wilks' lambda, Hotelling-Lawley trace, Pillai's trace, and Roy's largest root), these species have significant differences $(P<0.001)$ among the mean vectors from the 6 taxa. To understand the relationship of the significant differences among the 6 taxa of Reithrodontomys, we performed a discriminant analysis (Fig.2). The discriminant analysis correctly classified $100 \%$ of the specimens from the 6 taxa with 5 canonical variates. Three variates accounted for $96.1 \%$ of the variance, and the canonical correlations were 0.95 , 0.86 , and 0.77 , respectively (Table 2 ). The highly negative values in canonical variate 1 for all measurements except breadth of zygomatic plate suggest that size plays an important role in identification of Reithrodontomys species. Cranial breadth, greatest length of skull, zygomatic breadth, total length, and length of tail vertebrae are particularly important. The analysis indicates that as other measurements become larger, the breadth across the zygomatic plate varies in the opposite direction and becomes narrower. Reithrodantomys chrysopsis, R. sumichrasti, and R. megalotis are fairly well separated along the 1 st canonical variate with only some overlap between the first 2 species. The taxa R. f. toltecus, R. f. mustelinus, and $R$. microdon broadly overlap the other taxa along the 1st variate.

The highest positive weightings along canonical variate 2 are for length of tail vertebrae and total length, whereas the highest negative values were for breadth across the zygomatic plate and zygomatic breadth. The 2 taxa clearly separated from the others along canonical variate 2 were $R$. microdon and $R$. f. mustelinus. The 2 subspecies of $R$. fulvescens were clearly separated along canonical variate 2 (Fig. 2). Using only the first 2 canonical variates (accounting for $85.1 \%$ of total variance), only the taxa $R$. f. toltecus and R. sumichrasti were not separated from each other. This seems to indicate that these 2 taxa most closely resemble each other in external and cranial morphometrics among the 6 taxa occurring in the state of México. Ultimately, however, all taxa can be differentiated based on the measurements given herein.

There is good evidence of a relationship between the morphometric separation and habitat preferences among species of the genus Reithrodontomys in the state of México. In fact, 
TABLE 2. Results of a discriminant analysis of 65 specimens of Reithrodontomys from the state of México, with $100 \%$ correct classification. Acronyms are explained in the methods.

\begin{tabular}{llcr}
\hline Variable & \multicolumn{1}{c}{$\mathrm{CV}^{\mathrm{a}}$} & $\mathrm{CV} 2$ & $\mathrm{CV} 3$ \\
\hline TL & -0.432311 & 0.289363 & -0.147233 \\
TV & -0.44583 & 0.316854 & -0.056913 \\
HF & -0.344824 & 0.024895 & -0.385178 \\
LE & -0.266006 & -0.085493 & 0.105441 \\
GLS & -0.538076 & -0.286695 & -0.124636 \\
ZB & -0.494822 & -0.395939 & -0.086483 \\
CB & -0.668076 & -0.269575 & -0.006933 \\
IC & -0.2413 & 0.22392 & -0.067133 \\
BR & -0.192346 & 0.254884 & -0.568324 \\
LN & -0.399501 & -0.185197 & -0.071697 \\
MTR & -0.212583 & -0.291371 & -0.439342 \\
BZP & 0.068433 & -0.405147 & -0.245465 \\
BMF & -0.51557 & 0.161743 & 0.125782 \\
Canonical correlation & 0.95 & 0.86 & 0.77 \\
Eigenvalues & 8.35 & 2.78 & 1.44 \\
\% variance explained & 63.9 & 21.2 & 11 \\
\hline
\end{tabular}

aCanonical variate

the species that share habitats exhibit noticeable morphometric differences. For example, $R$. fulvenscens toltecus and R. sumichrasti with close morphometric similarities show considerable differences in habitat utilization; in contrast, $R$. fulvenscens toltecus and $R$. megalotis can be found in the same locality, but the morphometric differences are very strong (Fig. 2). The sequential expansion-retraction events postulated by Hooper (1952) would seem to explain the evolutionary processes that determined the taxonomic patterns and distribution of Reithrodontomys species in the Transvolcanic Belt. These events probably were responsible for habitat selection in the different species of the genus, as well as for size diversification within the genus.

\section{ACKNOWLEDGMENTS}

Our grateful thanks go to M. en C. Ticul Álvarez (deceased), former Curator, and Biól. Juan Carlos López Vidal, Curator of the Colección Mastozoológica de Escuela Nacional de Ciencias Biológicas, IPN, for permission to examine the specimens under their care. We give special thanks to 2 anonymous reviewers who enhanced our work through their valuable comments. This project was partially funded by grants from Consejo Nacional de Ciencia y Tecnología (CONACyT No. 39619Q-A to JRP. Our special thanks go to Miguel Bravo Rivera and Diana Irán López for preparing Fig. 1.

\section{Literature Cited}

Ceballos, G.G., and C.L. Galindo. 1984. Mamíferos silvestres de la Cuenca de México. Edit. Limusa, México.

Cervantes, F.A., G. Matamoros, and I. Martínez Mateos. 1995. Mamíferos silvestres de la Unidad de Evaluación y Monitoreo de la Biodiversidad "Ing. Luis Macías Arellano”, San Cayetano, Estado de México. Anales del Instituto de Biología, Universidad Nacional Autónoma de México, Serie Zoología 66:233239.

Chávez, C., and G. Ceballos. 1998. Diversidad y estado de conservación de los mamíferos del Estado de México. Revista Mexicana de Mastozoología 3:113134 .

Davis, W.B. 1944. Notes on Mexican mammals. Journal of Mammalogy 25:370-403.

Gaona, S., C. Galindo-Galindo, and M. GonzálezEscamilla. 2000. Ampliación y confirmación de la distribución de la ardilla voladora Glaucomys volans goldmani (Nelson, 1904). Vertebrata Mexicana 8:9-15.

HALL, E.R. 1981. The mammals of North America. 2nd edition. Volume 1. John Wiley \& Sons, Inc., New York.

HinTZE, J.L. 2000. NCSS 2000: statistical system for Windows. User's guide. NCSS, Kaysville, UT. Available from: http://www.ncss.com

Hooper, E.T. 1947. Notes on Mexican mammals. Journal of Mammalogy 28:40-57.

1952. A systematic review of the harvest mice (genus Reithrodontomys) of Latin America. Miscellaneous Publications, Museum of Zoology, University of Michigan 77:1-225.

1957. Records of Mexican mammals. Occasional Papers of the Museum of Zoology, University of Michigan 586:1-9.

Howell, A.H. 1914. Revision of the American harvest mice (genus Reithrodontomys). North American Fauna 36:1-97.

León P., L., AND E. Romo V. 1991. Catálogo de mamíferos (Vertebrata: Mammalia). Serie Catálogos del Museo 
de Zoología "Alfonso L. Herrera.” Facultad de Ciencias, Universidad Nacional Autónoma de México, Catálogo 2:1-68.

Mass, J., R. Patrón, A. Suárez, S. Blanco, G. Ceballos, C. Galindo, And A. Pescador. 1981. Ecología de la Estación Experimental Zoquiapan (Descripción general, vegetación y fauna). Universidad Autónoma Chapingo, Dirección de Difusión Cultural, Departamento de Bosques, Colección Cuadernos Universitarios 2:1-114.

MerRiam, C.H. 1900. Description of a new harvest mouse (Reithrodontomys) from México. Proceedings of the Biological Society of Washington 13:152.

1901. Descriptions of 23 new harvest mice (genus Reithrodontomys). Proceedings of Washington Academy of Sciences 3:547-558.

Motulsky, H.J. 2003. Prism 4 statistics guide—statistical analyses for laboratory and clinical researchers. GraphPad Prisma Software, Inc., San Diego, CA.

Ramírez-Pulido, J. 1969. Contribución al estudio de los mamíferos del Parque Nacional "Lagunas de Zempoala”, Morelos, México. Anales del Instituto de
Biología, Universidad Nacional Autónoma de México 40:253-290.

1995. Sinopsis de los mamíferos del Estado de México. Revista de la Sociedad Mexicana de Historia Natural 46:205-246.

Ramírez-Pulido, J., A. Castro-Campillo, and U. AguilERA. 1997. Capítulo III: Mamíferos. Pages 159-201 in Lista taxonómica de los vertebrados terrestres del Estado de México. Universidad Autónoma del Estado de México, Colección Ciencias y Técnicas 32:1-201.

SÁnCHEZ, O. 1993. Análisis de algunas tendencias ecogeográficas del género Reithrodontomys (Rodentia: Muridae). Pages 25-44 in R.A. Medellín and G. Ceballos, editors, Avances en el estudio de los mamíferos de México. Asociación Mexicana de Mastozoología, Publicaciones Especiales 1:1-464.

Villa-Ramírez, B. 1953. Mamíferos silvestres del Valle de México. Anales del Instituto de Biología, Universidad Nacional Autónoma de México 23:269-492.

Received 15 March 2006 Accepted 31 October 2006

APPENDIX. Localities of specimens of the genus Reithrodontomys housed in the Mammals Collection of the National School of Biological Sciences (Colección de Mamíferos de la Escuela Nacional de Ciencias Biológicas del Instituto Politécnico Nacional). The elevation is in meters $(\mathrm{m})$, and the geographic coordinates are degrees, minutes, and seconds. Localities are ordered according to latitude.

\begin{tabular}{|c|c|c|c|}
\hline No. & Locality & Latitude & Longitude \\
\hline 1 & $8 \mathrm{~km} \mathrm{~N}, 3 \mathrm{~km} \mathrm{~W}$ Aculco, $2250 \mathrm{~m}$ & $20^{\circ} 10^{\prime} 13^{\prime \prime}$ & $99^{\circ} 50^{\prime} 56^{\prime \prime}$ \\
\hline 2 & $3.5 \mathrm{~km} \mathrm{~N}, 19 \mathrm{~km} \mathrm{E}$ Aculco, $2650 \mathrm{~m}$ & $20^{\circ} 07^{\prime} 51^{\prime \prime}$ & $99^{\circ} 39^{\prime} 21^{\prime \prime}$ \\
\hline 3 & El Angostadero $23 \mathrm{~km}$ NW Acambay, $2700 \mathrm{~m}$ & $20^{\circ} 06^{\prime} 06^{\prime \prime}$ & $99^{\circ} 41^{\prime} 45^{\prime \prime}$ \\
\hline 4 & Llanos de Aculco, $3200 \mathrm{~m}$ & $20^{\circ} 05^{\prime} 54^{\prime \prime}$ & $99^{\circ} 49^{\prime} 37^{\prime \prime}$ \\
\hline 5 & $12.5 \mathrm{~km} \mathrm{~N}, 4.5 \mathrm{~km} \mathrm{~W}$ Acambay, $2450 \mathrm{~m}$ & $20^{\circ} 04^{\prime} 05^{\prime \prime}$ & $99^{\circ} 53^{\prime} 02^{\prime \prime}$ \\
\hline 6 & $9 \mathrm{~km} \mathrm{~N}, 7.5 \mathrm{~km}$ E Acambay, $2740 \mathrm{~m}$ & $20^{\circ} 02^{\prime} 09^{\prime \prime}$ & $99^{\circ} 46^{\prime} 33^{\prime \prime}$ \\
\hline 7 & $8.5 \mathrm{~km} \mathrm{~N}, 1.5 \mathrm{~km}$ E Acambay, $2740 \mathrm{~m}$ & $20^{\circ} 01^{\prime} 55^{\prime \prime}$ & $99^{\circ} 49^{\prime} 44^{\prime \prime}$ \\
\hline 8 & $8.5 \mathrm{~km} \mathrm{~N}, 2.5 \mathrm{~km}$ E Jilotepec, $2320 \mathrm{~m}$ & $20^{\circ} 01^{\prime} 46^{\prime \prime}$ & $99^{\circ} 30^{\prime} 43^{\prime \prime}$ \\
\hline 9 & $5 \mathrm{~km}$ E Jilotepec, $2460 \mathrm{~m}$ & $19^{\circ} 57^{\prime} 20^{\prime \prime}$ & $99^{\circ} 30^{\prime} 03^{\prime \prime}$ \\
\hline 10 & $4 \mathrm{~km} \mathrm{~N}, 1 \mathrm{~km}$ W Temascalcingo, $2360 \mathrm{~m}$ & $19^{\circ} 57^{\prime} 02^{\prime \prime}$ & $100^{\circ} 00^{\prime} 36^{\prime \prime}$ \\
\hline 11 & $9.5 \mathrm{~km} \mathrm{~N}$ Zumpango, $2270 \mathrm{~m}$ & $19^{\circ} 52^{\prime} 56^{\prime \prime}$ & $99^{\circ} 05^{\prime} 52^{\prime \prime}$ \\
\hline 12 & Santa María Cuevas, $2480 \mathrm{~m}$ & $19^{\circ} 52^{\prime} 00^{\prime \prime}$ & $99^{\circ} 05^{\prime} 47^{\prime \prime}$ \\
\hline 13 & $6.5 \mathrm{~km} \mathrm{~S}, 6 \mathrm{~km} \mathrm{~W}$ Temascalcingo, $2560 \mathrm{~m}$ & $19^{\circ} 51^{\prime} 23^{\prime \prime}$ & $100^{\circ} 03^{\prime} 00^{\prime \prime}$ \\
\hline 14 & $2.5 \mathrm{~km}$ N San Juan Zitlaltepec, $2250 \mathrm{~m}$ & $19^{\circ} 49^{\prime} 55^{\prime \prime}$ & $99^{\circ} 08^{\prime} 52^{\prime \prime}$ \\
\hline 15 & 9 km N Villa del Carbón, 2400 m & $19^{\circ} 48^{\prime} 30^{\prime \prime}$ & $99^{\circ} 27^{\prime} 43^{\prime \prime}$ \\
\hline 16 & $0.25 \mathrm{~km} \mathrm{~S}, 2.25 \mathrm{~km}$ E San Pedro Atlapulco, $3100 \mathrm{~m}$ & $19^{\circ} 47^{\prime} 42^{\prime \prime}$ & $99^{\circ} 51^{\prime} 14^{\prime \prime}$ \\
\hline 17 & $2.7 \mathrm{~km} \mathrm{~N}, 9 \mathrm{~km}$ W Villa del Carbón, $2670 \mathrm{~m}$ & $19^{\circ} 45^{\prime} 08^{\prime \prime}$ & $99^{\circ} 22^{\prime} 55^{\prime \prime}$ \\
\hline 18 & $2 \mathrm{~km}$ NW Santiago Tolman, $2600 \mathrm{~m}$ & $19^{\circ} 44^{\prime} 25^{\prime \prime}$ & $98^{\circ} 48^{\prime} 03^{\prime \prime}$ \\
\hline 19 & San Felipe del Progreso, $2620 \mathrm{~m}$ & $19^{\circ} 42^{\prime} 45^{\prime \prime}$ & $99^{\circ} 57^{\prime} 04^{\prime \prime}$ \\
\hline 20 & $2 \mathrm{~km} \mathrm{~S}, 3 \mathrm{~km}$ E Chilpa, $2270 \mathrm{~m}$ & $19^{\circ} 42^{\prime} 05^{\prime \prime}$ & $100^{\circ} 00^{\prime} 36^{\prime \prime}$ \\
\hline 21 & $4 \mathrm{~km} \mathrm{~W} \mathrm{La} \mathrm{Providencia,} 3050 \mathrm{~m}$ & $19^{\circ} 41^{\prime} 52^{\prime \prime}$ & $99^{\circ} 47^{\prime} 24^{\prime \prime}$ \\
\hline 22 & $2.5 \mathrm{~km}$ W San Francisco Tepojaco, $2350 \mathrm{~m}$ & $19^{\circ} 39^{\prime} 30^{\prime \prime}$ & $97^{\circ} 13^{\prime} 08^{\prime \prime}$ \\
\hline 23 & 1 km S, 3 km W San José del Rincón, 2960 m & $19^{\circ} 39^{\prime} 05^{\prime \prime}$ & $100^{\circ} 10^{\prime} 11^{\prime \prime}$ \\
\hline 24 & San Sebastiaen Shala, FES Cuatitlán & $19^{\circ} 38^{\prime} 46^{\prime \prime}$ & $99^{\circ} 12^{\prime} 41^{\prime \prime}$ \\
\hline 25 & $3 \mathrm{~km}$ E Popo Park, $2480 \mathrm{~m}$ & $19^{\circ} 38^{\prime} 45^{\prime \prime}$ & $98^{\circ} 45^{\prime} 07^{\prime \prime}$ \\
\hline 26 & $1 \mathrm{~km} \mathrm{~S}, 2$ km E Nicolás Romero, $2350 \mathrm{~m}$ & $19^{\circ} 36^{\prime} 56^{\prime \prime}$ & $99^{\circ} 17^{\prime} 41^{\prime \prime}$ \\
\hline 27 & $2 \mathrm{~km} \mathrm{~S}$ Coacalco, $2440 \mathrm{~m}$ & $19^{\circ} 36^{\prime} 55^{\prime \prime}$ & $99^{\circ} 05^{\prime} 34^{\prime \prime}$ \\
\hline 28 & $1.1 \mathrm{~km}$ N Barrientos, $2300 \mathrm{~m}$ & $19^{\circ} 35^{\prime} 38^{\prime \prime}$ & $99^{\circ} 13^{\prime} 22^{\prime \prime}$ \\
\hline 29 & $4.5 \mathrm{~km}$ E Chiconautla, $2350 \mathrm{~m}$ & $19^{\circ} 35^{\prime} 14^{\prime \prime}$ & $99^{\circ} 02^{\prime} 20^{\prime \prime}$ \\
\hline 30 & $2 \mathrm{~km}$ NE Chimalpa, $2700 \mathrm{~m}$ & $19^{\circ} 34^{\prime} 55^{\prime \prime}$ & $98^{\circ} 52^{\prime} 44^{\prime \prime}$ \\
\hline 31 & $1 \mathrm{~km} \mathrm{~S}, 2 \mathrm{~km}$ W Chimalpa, $2900 \mathrm{~m}$ & $19^{\circ} 33^{\prime} 36^{\prime \prime}$ & $98^{\circ} 54^{\prime} 36^{\prime \prime}$ \\
\hline 32 & $2 \mathrm{~km} \mathrm{NW}$ Tlanepantla, $2300 \mathrm{~m}$ & $19^{\circ} 32^{\prime} 58^{\prime \prime}$ & $99^{\circ} 12^{\prime} 25^{\prime \prime}$ \\
\hline 33 & $4 \mathrm{~km} \mathrm{~N} \mathrm{Temoaya,} 2870 \mathrm{~m}$ & $19^{\circ} 30^{\prime} 16^{\prime \prime}$ & $99^{\circ} 35^{\prime} 34^{\prime \prime}$ \\
\hline 34 & $6 \mathrm{~km} \mathrm{~N}, 2.5 \mathrm{~km} \mathrm{~W}$ Villa Victoria, $2710 \mathrm{~m}$ & $19^{\circ} 29^{\prime} 32^{\prime \prime}$ & $99^{\circ} 58^{\prime} 37^{\prime \prime}$ \\
\hline 35 & Criadero San Cayetano $8 \mathrm{~km}$ NW Villa Victoria & $19^{\circ} 28^{\prime} 59^{\prime \prime}$ & $100^{\circ} 03^{\prime} 00^{\prime \prime}$ \\
\hline
\end{tabular}


ApPendix. Continued.

\begin{tabular}{|c|c|c|c|}
\hline No. & Locality & Latitude & Longitude \\
\hline 36 & Cuesta del Carmen $3 \mathrm{~km} \mathrm{N,} 1 \mathrm{~km} \mathrm{~W}$ Lengua de Vaca, $2760 \mathrm{~m}$ & $19^{\circ} 28^{\prime} 39^{\prime \prime}$ & $100^{\circ} 11^{\prime} 24^{\prime \prime}$ \\
\hline 37 & 6 km NW Villa Victoria, $2400 \mathrm{~m}$ & $19^{\circ} 28^{\prime} 32^{\prime \prime}$ & $99^{\circ} 57^{\prime} 25^{\prime \prime}$ \\
\hline 38 & $16 \mathrm{~km} \mathrm{SW}$ Texcoco, $2220 \mathrm{~m}$ & $19^{\circ} 24^{\prime} 13^{\prime \prime}$ & $98^{\circ} 46^{\prime} 44^{\prime \prime}$ \\
\hline 39 & $4.5 \mathrm{~km} \mathrm{~S}, 10 \mathrm{~km} \mathrm{~W}$ Villa Victoria, $2560 \mathrm{~m}$ & $19^{\circ} 23^{\prime} 48^{\prime \prime}$ & $99^{\circ} 54^{\prime} 17^{\prime \prime}$ \\
\hline 40 & $2.5 \mathrm{~km} \mathrm{~N}, 1.5 \mathrm{~km} \mathrm{~W}$ Huixquilucan, $2800 \mathrm{~m}$ & $19^{\circ} 23^{\prime} 01^{\prime \prime}$ & $99^{\circ} 21^{\prime} 50^{\prime \prime}$ \\
\hline 41 & 9 km W Río Frío, 3050 m & $19^{\circ} 21^{\prime} 09^{\prime \prime}$ & $98^{\circ} 45^{\prime} 03^{\prime \prime}$ \\
\hline 42 & 2 km S, 5 km W Río Frío, 3100 m & $19^{\circ} 20^{\prime} 04^{\prime \prime}$ & $98^{\circ} 42^{\prime} 53^{\prime \prime}$ \\
\hline 43 & $3 \mathrm{~km} \mathrm{~S}$ Huixquilucan, $3000 \mathrm{~m}$ & $19^{\circ} 20^{\prime} 03^{\prime \prime}$ & $99^{\circ} 20^{\prime} 59^{\prime \prime}$ \\
\hline 44 & 3 km W Río Frío, 3000 m & $19^{\circ} 19^{\prime} 57^{\prime \prime}$ & $98^{\circ} 41^{\prime} 49^{\prime \prime}$ \\
\hline 45 & 3 km S, 4 km W Río Frío, 3290 m & $19^{\circ} 19^{\prime} 31^{\prime \prime}$ & $98^{\circ} 42^{\prime} 21^{\prime \prime}$ \\
\hline 46 & Salazar, $3050 \mathrm{~m}$ & $19^{\circ} 18^{\prime} 25^{\prime \prime}$ & $99^{\circ} 23^{\prime} 17^{\prime \prime}$ \\
\hline 47 & $3 \mathrm{~km} \mathrm{~S}$ Tlapacoya, $2250 \mathrm{~m}$ & $19^{\circ} 18^{\prime} 08^{\prime \prime}$ & $98^{\circ} 52^{\prime} 26^{\prime \prime}$ \\
\hline 48 & $5 \mathrm{~km} \mathrm{~W}$ Atenco & $19^{\circ} 16^{\prime} 13^{\prime \prime}$ & $99^{\circ} 34^{\prime} 37^{\prime \prime}$ \\
\hline 49 & $4 \mathrm{~km} \mathrm{~N}, 1.5 \mathrm{~km}$ E Santiago Tilapa, $2750 \mathrm{~m}$ & $19^{\circ} 13^{\prime} 17^{\prime \prime}$ & $99^{\circ} 24^{\prime} 21^{\prime \prime}$ \\
\hline 50 & $1.5 \mathrm{~km} \mathrm{~S}, 5 \mathrm{~km}$ E San Rafael & $19^{\circ} 11^{\prime} 43^{\prime \prime}$ & $98^{\circ} 42^{\prime} 43^{\prime \prime}$ \\
\hline 51 & $1 \mathrm{~km} \mathrm{E}$ Capulhuac, $2600 \mathrm{~m}$ & $19^{\circ} 11^{\prime} 29^{\prime \prime}$ & $99^{\circ} 27^{\prime} 18^{\prime \prime}$ \\
\hline 52 & $3 \mathrm{~km} \mathrm{SW}$ Valle de Bravo, $2060 \mathrm{~m}$ & $19^{\circ} 10^{\prime} 22^{\prime \prime}$ & $100^{\circ} 06^{\prime} 36^{\prime \prime}$ \\
\hline 53 & Cerro Ayaqueme $6 \mathrm{~km} \mathrm{N,} 6.5 \mathrm{~km}$ W Juchitepec, $2910 \mathrm{~m}$ & $19^{\circ} 09^{\prime} 14^{\prime \prime}$ & $98^{\circ} 56^{\prime} 20^{\prime \prime}$ \\
\hline 54 & $15 \mathrm{~km} \mathrm{S,} 7 \mathrm{~km} \mathrm{~W}$ Zinacantepec, $3470 \mathrm{~m}$ & $19^{\circ} 08^{\prime} 57^{\prime \prime}$ & $99^{\circ} 40^{\prime} 11^{\prime \prime}$ \\
\hline 55 & $11 \mathrm{~km} \mathrm{~S}, 2.5 \mathrm{~km}$ W San Juan de las Huertas, $3780 \mathrm{~m}$ & $19^{\circ} 08^{\prime} 45^{\prime \prime}$ & $99^{\circ} 46^{\prime} 40^{\prime \prime}$ \\
\hline 56 & $11.5 \mathrm{~km} \mathrm{~S}, 2.5 \mathrm{~km} \mathrm{~W}$ San Juan de las Huetas, $3780 \mathrm{~m}$ & $19^{\circ} 08^{\prime} 45^{\prime \prime}$ & $99^{\circ} 46^{\prime} 58^{\prime \prime}$ \\
\hline 57 & $15.5 \mathrm{~km} \mathrm{~S}, 7 \mathrm{~km} \mathrm{~W}$ Zinacatepec, $3470 \mathrm{~m}$ & $19^{\circ} 08^{\prime} 43^{\prime \prime}$ & $99^{\circ} 40^{\prime} 11^{\prime \prime}$ \\
\hline 58 & $12 \mathrm{~km}$ S San Juan de las Huertas, $3850 \mathrm{~m}$ & $19^{\circ} 08^{\prime} 15^{\prime \prime}$ & $99^{\circ} 45^{\prime} 21^{\prime \prime}$ \\
\hline 59 & $5 \mathrm{~km}$ S Santiago Tianguistenco, $2620 \mathrm{~m}$ & $19^{\circ} 08^{\prime} 07^{\prime \prime}$ & $99^{\circ} 28^{\prime} 04^{\prime \prime}$ \\
\hline 60 & $10 \mathrm{~km} \mathrm{~N}, 12.4 \mathrm{~km}$ E Temascaltepec, $2450 \mathrm{~m}$ & $19^{\circ} 08^{\prime} 02^{\prime \prime}$ & $99^{\circ} 55^{\prime} 40^{\prime \prime}$ \\
\hline 61 & Texcalyacac, $2570 \mathrm{~m}$ & $19^{\circ} 07^{\prime} 52^{\prime \prime}$ & $99^{\circ} 30^{\prime} 05^{\prime \prime}$ \\
\hline 62 & $18.5 \mathrm{~km} \mathrm{~S}, 9 \mathrm{~km} \mathrm{~W}$ Zinacatepec, $3440 \mathrm{~m}$ & $19^{\circ} 07^{\prime} 47^{\prime \prime}$ & $99^{\circ} 39^{\prime} 10^{\prime \prime}$ \\
\hline 63 & Nevado de Toluca 4 km S, 2 km W Raíces, 3350 m & $19^{\circ} 07^{\prime} 26^{\prime \prime}$ & $99^{\circ} 49^{\prime} 19^{\prime \prime}$ \\
\hline 64 & Nevado de Toluca & $19^{\circ} 07^{\prime} 25^{\prime \prime}$ & $99^{\circ} 49^{\prime} 15^{\prime \prime}$ \\
\hline 65 & $600 \mathrm{~m}$ SW Tlamacas, $4000 \mathrm{~m}$ & $19^{\circ} 06^{\prime} 15^{\prime \prime}$ & $98^{\circ} 46^{\prime} 15^{\prime \prime}$ \\
\hline 66 & $2.2 \mathrm{~km} \mathrm{~N}, 6.5 \mathrm{~km}$ E San Pedro Nexapa, $3490 \mathrm{~m}$ & $19^{\circ} 06^{\prime} 10^{\prime \prime}$ & $98^{\circ} 40^{\prime} 33^{\prime \prime}$ \\
\hline 67 & $7.5 \mathrm{~km}$ E Tenango de Arista, $2600 \mathrm{~m}$ & $19^{\circ} 06^{\prime} 09^{\prime \prime}$ & $99^{\circ} 39^{\prime} 21^{\prime \prime}$ \\
\hline 68 & $1.6 \mathrm{~km} \mathrm{~N}, 6.4$ km E San Pedro Nexapa, $3200 \mathrm{~m}$ & $19^{\circ} 05^{\prime} 51^{\prime \prime}$ & $98^{\circ} 40^{\prime} 37^{\prime \prime}$ \\
\hline 69 & $7 \mathrm{~km}$ SE San Nicolas Coatepec, $2740 \mathrm{~m}$ & $19^{\circ} 05^{\prime} 49^{\prime \prime}$ & $99^{\circ} 22^{\prime} 44^{\prime \prime}$ \\
\hline 70 & $1.5 \mathrm{~km} \mathrm{~N}, 4 \mathrm{~km}$ E San Pedro Nexapa, $2940 \mathrm{~m}$ & $19^{\circ} 05^{\prime} 47^{\prime \prime}$ & $98^{\circ} 41^{\prime} 56^{\prime \prime}$ \\
\hline 71 & $4 \mathrm{~km} \mathrm{~S}, 9 \mathrm{~km}$ E Amecameca, $3480 \mathrm{~m}$ & $19^{\circ} 05^{\prime} 33^{\prime \prime}$ & $98^{\circ} 40^{\prime} 48^{\prime \prime}$ \\
\hline 72 & $8 \mathrm{~km} \mathrm{~N}, 17.5$ km E San Simón de Guerrero, 2940 m & $19^{\circ} 05^{\prime} 30^{\prime \prime}$ & $99^{\circ} 52^{\prime} 04^{\prime \prime}$ \\
\hline 73 & $5 \mathrm{~km} \mathrm{~N}, 2 \mathrm{~km}$ E Real de Arriba, $1980 \mathrm{~m}$ & $19^{\circ} 05^{\prime} 04^{\prime \prime}$ & $99^{\circ} 59^{\prime} 06^{\prime \prime}$ \\
\hline 74 & $1.5 \mathrm{~km}$ E San Pedro Nexapa, $2700 \mathrm{~m}$ & $19^{\circ} 04^{\prime} 59^{\prime \prime}$ & $98^{\circ} 43^{\prime} 15^{\prime \prime}$ \\
\hline 75 & $5.2 \mathrm{~km}$ E San Pedro Nexapa, $3250 \mathrm{~m}$ & $19^{\circ} 04^{\prime} 59^{\prime \prime}$ & $98^{\circ} 41^{\prime} 16^{\prime \prime}$ \\
\hline 76 & $5.5 \mathrm{~km}$ E San Pedro Nexapa, $3250 \mathrm{~m}$ & $19^{\circ} 04^{\prime} 59^{\prime \prime}$ & $98^{\circ} 41^{\prime} 05^{\prime \prime}$ \\
\hline 77 & $6 \mathrm{~km} \mathrm{~S}$ Amecameca, $2450 \mathrm{~m}$ & $19^{\circ} 04^{\prime} 24^{\prime \prime}$ & $98^{\circ} 45^{\prime} 43^{\prime \prime}$ \\
\hline 78 & $1 \mathrm{~km}$ SW Zacazonapan, $1320 \mathrm{~m}$ & $19^{\circ} 03^{\prime} 59^{\prime \prime}$ & $100^{\circ} 14^{\prime} 23^{\prime \prime}$ \\
\hline 79 & $2.5 \mathrm{~km}$ E Popo Park, $2470 \mathrm{~m}$ & $19^{\circ} 03^{\prime} 51^{\prime \prime}$ & $98^{\circ} 45^{\prime} 25^{\prime \prime}$ \\
\hline 80 & $1 \mathrm{~km} \mathrm{~N}, 0.6$ km E San Juan Tehuixtlán, 2480 m & $19^{\circ} 03^{\prime} 41^{\prime \prime}$ & $98^{\circ} 46^{\prime} 19^{\prime \prime}$ \\
\hline 81 & $6 \mathrm{~km} \mathrm{~S}, 8.5 \mathrm{~km} \mathrm{~W}$ Tenango de Arista, $2750 \mathrm{~m}$ & $19^{\circ} 02^{\prime} 52^{\prime \prime}$ & $99^{\circ} 30^{\prime} 39^{\prime \prime}$ \\
\hline 82 & $6 \mathrm{~km} \mathrm{E,} 4 \mathrm{~km} \mathrm{~S} \mathrm{San} \mathrm{Pedro} \mathrm{Nexapa,} 3050 \mathrm{~m}$ & $19^{\circ} 02^{\prime} 50^{\prime \prime}$ & $98^{\circ} 40^{\prime} 48^{\prime \prime}$ \\
\hline 83 & $4 \mathrm{~km} \mathrm{~S}, 8.5 \mathrm{~km}$ E San Pedro Nexapa, $3500 \mathrm{~m}$ & $19^{\circ} 02^{\prime} 49^{\prime \prime}$ & $98^{\circ} 39^{\prime} 28^{\prime \prime}$ \\
\hline 84 & $7 \mathrm{~km}$ SE San Pedro Nexapa, $3010 \mathrm{~m}$ & $19^{\circ} 02^{\prime} 45^{\prime \prime}$ & $98^{\circ} 40^{\prime} 58^{\prime \prime}$ \\
\hline 85 & $3 \mathrm{~km} \mathrm{~S}$ Temascaltepec, $1900 \mathrm{~m}$ & $19^{\circ} 00^{\prime} 56^{\prime \prime}$ & $100^{\circ} 02^{\prime} 24^{\prime \prime}$ \\
\hline 86 & $2.5 \mathrm{~km} \mathrm{NE} \mathrm{Ecatzingo,} 2600 \mathrm{~m}$ & $18^{\circ} 58^{\prime} 19^{\prime \prime}$ & $98^{\circ} 44^{\prime} 13^{\prime \prime}$ \\
\hline 87 & $1.5 \mathrm{~km} \mathrm{~N}, 5.5 \mathrm{~km} \mathrm{E}$ Ecatzingo, $2970 \mathrm{~m}$ & $18^{\circ} 58^{\prime} 12^{\prime \prime}$ & $98^{\circ} 42^{\prime} 10^{\prime \prime}$ \\
\hline 88 & Jalmolonga, $1600 \mathrm{~m}$ & $18^{\circ} 55^{\prime} 06^{\prime \prime}$ & $99^{\circ} 29^{\prime} 37^{\prime \prime}$ \\
\hline 89 & Cañada de Nanchitita, $1900 \mathrm{~m}$ & $18^{\circ} 51^{\prime} 47^{\prime \prime}$ & $100^{\circ} 27^{\prime} 00^{\prime \prime}$ \\
\hline 90 & Zumpahuacan, $1630 \mathrm{~m}$ & $18^{\circ} 50^{\prime} 11^{\prime \prime}$ & $99^{\circ} 34^{\prime} 43^{\prime \prime}$ \\
\hline 91 & $3 \mathrm{~km} \mathrm{~S}, 8 \mathrm{~km} \mathrm{~W}$ Sultepec, $1300 \mathrm{~m}$ & $18^{\circ} 49^{\prime} 53^{\prime \prime}$ & $100^{\circ} 01^{\prime} 47^{\prime \prime}$ \\
\hline 92 & $11 \mathrm{~km} \mathrm{~S}, 2.5 \mathrm{~km}$ W Coatepec de Harinas, $2870 \mathrm{~m}$ & $18^{\circ} 49^{\prime} 30^{\prime \prime}$ & $99^{\circ} 47^{\prime} 27^{\prime \prime}$ \\
\hline 93 & $2 \mathrm{~km}$ E Tonatico & $18^{\circ} 48^{\prime} 02^{\prime \prime}$ & $99^{\circ} 39^{\prime} 03^{\prime \prime}$ \\
\hline 94 & $5 \mathrm{~km} \mathrm{~S}, 5.5 \mathrm{~km} \mathrm{E}$ Tonatico, $1590 \mathrm{~m}$ & $18^{\circ} 46^{\prime} 38^{\prime \prime}$ & $99^{\circ} 37^{\prime} 01^{\prime \prime}$ \\
\hline 95 & $5 \mathrm{~km} \mathrm{~S}, 5 \mathrm{~km} \mathrm{~W}$ Palmar Chico, $1180 \mathrm{~m}$ & $18^{\circ} 38^{\prime} 57^{\prime \prime}$ & $100^{\circ} 24^{\prime} 36^{\prime \prime}$ \\
\hline
\end{tabular}

